\title{
Spatial Distribution Model for Targeting the Support for Cultural Institutions' Development: A Case Study of Slovakia
}

\author{
Kristína Baculáková - Martin Grešš
}

\author{
Kristína Baculáková \\ University of Economics \\ Faculty of International Relations \\ Bratislava \\ Slovakia \\ e-mail: kristina.baculakova@euba.sk \\ ORCID: 0000-0002-0143-7541 \\ Martin Grešš \\ University of Economics \\ Faculty of International Relations, \\ Bratislava \\ Slovakia \\ e-mail: martin.gress@euba.sk \\ ORCID: 0000-0003-1655-043X
}

Mureológia a kultúrne dedičstvo, 2021, 9:3:93-112

DOI: $10.46284 / \mathrm{mkd} .2021 .9 .3 .5$

\begin{abstract}
Spatial Distribution Model for Targeting the Support for Cultural Institutions' Development: A Case Study of Slovakia

Culture is one of the main tools for developing regions and reducing regional disparities. It is a significant job creator; it participates in social cohesion representing a catalyst for economic growth. In practice, when boosting the potential of cultural and creative industries, we encounter an insufficiently developed approach to evaluating the initial conditions for the allocation of financial resources for its development. This paper's objective is to identify, map, and analyse spatial concentration of cultural institutions in Slovakia. The intention of the analysis was the identification of regions and districts with the potential for full use of cultural capital as a tool for sustainable regional development as well as the setting of cultural policy. The cluster analysis pointed out significant differences in the representation of cultural institutions in individual regions and districts of Slovakia. The regions with the most desirable results (e.g., Bratislava, Trnava, or Nitra) have some common characteristics linked to the local context, such as historical development, good infrastructure, concentration of educational institutions. The results also confirmed the assumption that within the regions, cultural institutions will be concentrated in larger district cities, specifically in the case of Bratislava even inside the city. From the cluster analysis it is possible to observe a "belt of districts" of Southern, Central, and Eastern Slovakia, which do not have sufficient cultural infrastructure. Since the process of shaping the supportive policy for cultural industries is now ongoing in Slovakia, we consider mapping the situation as one of the key elements in the policy-making process.
\end{abstract}

Keywords: spatial differentiation, cultural institutions, cluster analysis, regional development, Slovakia

\section{Introduction}

In recent years, not only in Slovakia, but throughout the European Union, there has been a revival of interest in culture. The multidisciplinarity of cultural research is the object of reflection of culturology, ethnology, cultural anthropology, and sociology, but also cultural geography. In the context of current social changes, it seems necessary to link the theoretical explanations of these scientific disciplines with practice, especially in the field of applied 
K. Baculáková - M. Grešš: Spatial Distribution Model for Targeting the Support...

practice of cultural policy.

Culture is one of the main tools for developing regions and reducing regional disparities. It is a creator of new jobs; it participates in social cohesion and is thus a catalyst for economic growth. In practice, an inclusive approach to culture is increasingly being used. Its economisation is a consequence of the requirement to use the full potential of culture in creating capital. With this approach, the question of the negative consequences of commoditising culture comes to the fore. Discovering the potential of cultural products and services in the last twenty years has attracted the attention of politicians and economists. The potential of the cultural and creative industries even seemed to be so great that, unlike other industries, it also withstood the consequences of the crisis, or even grew during the crisis. However, the share of these sectors in GDP or employment is still very low compared to other industries.

The presented article focuses on the use of cultural potential in the context of regional development. The aim is to map the spatial concentration of cultural institutions in individual regions and districts of the Slovak Republic. Cultural institutions, as the basic units for the use of cultural potential, contribute to local and regional development. We perceive their mapping as important from the point of view of the correct setting of cultural policy and culture development strategy for the next financing period of 2020-2027.

\section{Literature Review}

The literature deals with the issue of the relation between culture and regional development in terms of two aspects, which we used in further analysis. The first is the definition of culture itself, categorisation of cultural potential, and examination of its impact in the context of regional development. This relation began to be the subject of research in the 1990 s, with cultural capital being the aspect or manifestation of culture that contributes to local and regional development. Cultural capital as an asset is created by the transformation of cultural potential, so we focus on the analysis of the relationships between its elements. The second aspect, on which we place the greatest emphasis, is the study of the spatial concentration of culture, specifically in the form of the concentration of cultural industries. Most theories examining spatial concentration are based on endogenous concepts of development, i.e., they analyse the mobilisation and use of the so-called internal resources as a key factor for growth.

\subsection{Culture, cultural potential, and regional development}

Culture can be defined as a set of opinions, beliefs, habits, and values that are shared by a certain group of people. Tylor sees culture as "that complex whole which includes knowledge, belief, art, law, morals, custom, and any other capabilities and habits acquired by man as a member of society." It is the activity of people and the products of this activity which have certain moral, intellectual, and artistic aspects. Slušná defines culture in three ways. In a narrow sense, it is defined as a sector of art, which includes mainly classical music, literature, and theatre, but also popular mass art. In a broader sense, it is also defined as everyday manifestations of culture with a formal and symbolic character, such as rituals, symbols, practices, clothing, and eating, but also the culture of politics. In the broadest sense, she understands culture in all its manifestations, norms, values, and beliefs. These are, in particular, typical and characteristic of a particular community or society.

Man was not born with culture, but acquired it through a process of adaptation. 
Culture is a product of man as a member of a community, not as an individual. It is the result of collective experience, but each culture is unique. The culture is continuous, but not immutable. It must be constantly improved. Thus, one of the most important features of culture is cultivation. Culture shapes and cultivates the behaviour and thoughts of the individual in a particular society and social situation. It is always born in a group and is the legacy of generations. Cultures are very different, but their development is related to their ability to adapt to the material world. Culture can be perceived through both its manifestations and characteristics. Manifestations of culture can be symbolic (ideas, values, customs, norms), material (artifacts, works of art, clothing), but also normative (morality, ethical and social norms).

Culture is the collective program of the human mind. Collective values thus shape individual regions. Culture is an important factor in local and regional development. Ilmonen emphasises that if the region wants to ensure sustainable growthin thelong term, it must be based notonly on economic theories butalso social sciences, especially cultural studies, in planning and securing it. The trend of exploring culture in the context of regional development began in the 1990s. The OECD's Culture and Local Development document has already emphasised the need to strengthen regional and local cultural capital as a basis for a region's development. Regional development is also closely related to quality of life. Cultural capital was first defined as one of the three basic forms of capital in Bordieu's work (1986).

Cultural capital can exist in three forms: in the embodied state, i.e., in the form of longlasting dispositions of the mind and body; in the objectified state, in the form of cultural goods (pictures, books, dictionaries, instruments, machines, etc.) and in the institutionalised state... According to Janto, the cultural capital of a locality can be most easily characterised as local tangible and intangible cultural phenomena that have a certain social value and significance, and can be used in renewal or development.

Fig. 1. Diagram of cultural potential

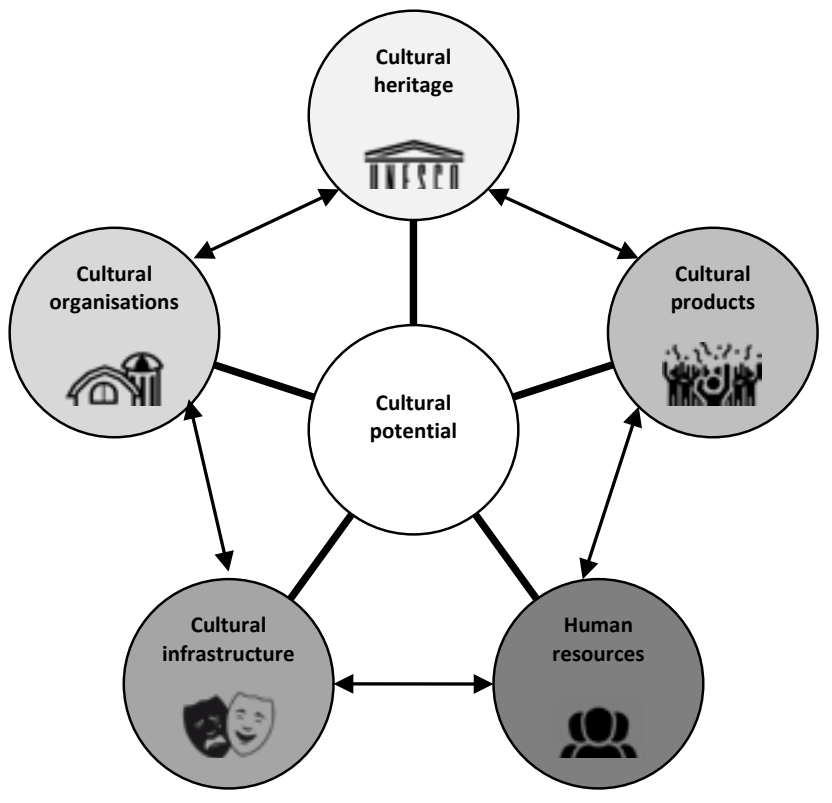


K. Baculáková - M. Grešš: Spatial Distribution Model for Targeting the Support...

Culture influences the quality of life primarily through its subjective perception. In his analysis of quality of life,Murgašapproaches culturalcapitalholistically, understandingitas anintegral part of humancapital, which hedescribesas one of thekeyendogenous factorsinfluencingqualityof life.

Cultural capital is created by the correct use of cultural potential. Cultural potential is the sum of cultural values-cultural phenomena and their individual componentsand cultural elements that can be used; the whole complex of cultural heritage, noninstitutional as well as organised production of institutions providing cultural services. In the publication of Lenovský et al., the cultural potential consists of five components, namely cultural heritage, cultural and social organisations and other institutions, cultural events and cultural products, cultural infrastructure, and finally human resources in the cultural sector. The individual components interact with each other (Fig. 1).

Klein et al. ${ }^{1}$ carried out a study emphasising that one of the factors influencing the socioeconomic dynamics of a place or region is cultural vitality. Cultural vitality can be understood as a set of characteristics of the place-the presence of organisations active in cultural industries and the cultural activity itself, its administration, financial and organisational resources, as well as cultural identity. However, awareness of one's own cultural identity does not arise in a social group or in an individual for no reason. This identity has primarily a communicative role, both externally (between cultures) and inwardly (within a particular culture). ${ }^{2}$ Jackson, Kabwasa-Green, and Herranz $z^{3}$ drew up a definition of cultural vitality based on its three dimensions: cultural viability as the existence of opportunities to engage in cultural activities, the very involvement of cultural activities, and finally the promotion of those cultural activities. The third dimension is also a space for cultural policy-making.

In our paper we focus on cultural institutions such as the so-called cultural actors. We start from the classification of Lenovský et al. Cultural institutions are involved in the development of cultural life at the regional and local levels. The cultural institutions that enter into the analysis in our paper have a clear formal structure, a defined competence framework in which they carry out their activities, and professional staff. Cultural institutions are also a tool for implementing the state cultural policy. However, the changing conditions in the field of financing cultural activities and the emergence of the dual principle in the practice of cultural institutions after 1989 also meant that in addition to non-profit and financially subsidised institutions, private institutions also appeared in the culture and arts market, thus increasing competition in this market. ${ }^{4} \mathrm{Cultural}$ institutions are also preservers and presenters of cultural heritage. This forms the complete basis of the country's cultural potential. Cultural heritage, both tangible and intangible, can therefore be a significant cultural asset of a municipality or city. And as a cultural asset, it also means a competitive advantage. Thus, culture can be an important factor in regional and local development. However, if the cultural potential is to be fully realised, the role of cultural institutions will also be to ensure an innovative approach to mediating cultural values to the public. ${ }^{5}$ An innovative

\footnotetext{
${ }^{1}$ KLEIN, Juan Luis et al. Cultural Initiatives and Local Development: A Basis for Inclusive Neighborhood Revitalization. In: Urban Planning, 4(1), 2019, pp. 78-90. 10.17645/up.v4i1.1658.2012.

${ }^{2}$ MISTRÍK, Erich et al. Kultúra a multikultúrna výchova. Bratislava: Iris, 1999.

${ }^{3}$ JACKSON, Maria, KABWASA-GREEN, F., \& HERRANZ, J. R. Cultural Vitality in Communities: Interpretation and Indicators. Washington DC: The Urban Institute, 2006.

${ }^{4}$ PRAVDOVÁ, Hana. Manažment a marketing v kultuirnych inštitúciách. Bratislava: Univerzita Komenského, 2015, p. 5.

${ }^{5}$ MINISTERSTVO KULTÚRY SR. Stratégia rozvoja kultúry Slovenskej republiky na roky 2014-2020, 2014, accessed November 2nd, 2020, http://www.strategiakultury.sk/sites/default/files/STRATEGIAROZVOJA_

KULTURY_SR_NA_ROKY_2014-2020.pdf
} 
approach also requires sufficient funding for cultural institutions.

\subsection{Spatial concentration of cultural industries and regional development}

As Gažová says, culture is not just an object among other objects. One of its features is the crossing of geographical and social boundaries. ${ }^{6}$ And it is the imaginary geographical boundaries that we will address in the next section. Most theories that examine the impact of culture and cultural industries or the creative industry on regional growth are based on endogenous concepts of development. ${ }^{7}$ This means that the development of cities and regions is determined by the use of internal resources. This is the basic economic premise. The basis of empirical research of cultural industries is, in addition to the quantification of economic indicators, also the determination of spatial concentration. ${ }^{8}$ Determining spatial concentration is also the most widely used method of research, which detects, for example, clustering, the concentration of the creative class, or individual components of the Creativity Index. ${ }^{9}$

Geographical analysis of the distribution of these sectors enables better creation of conditions for their development and functioning and more efficient allocation of public resources. Theories are based not only on cultural geography, which examines the spatial differentiation of different cultures and their manifestations, and thus actually analyses the influence and behaviour of culture from an anthropological and sociological point of view, ${ }^{10}$ but also on the so-called geography of cultural industries. ${ }^{11}$ As the Slovak scientist Žigrai says, cultural geography examines the laws and causes of the spatial expansion and arrangement of individual cultural and spiritual values created by man in time and space, as well as the relationships between them and the surrounding natural and social environment. ${ }^{12}$ Geography of cultural and creative industries not only offers a view of the spatial distribution of industries, but can monitor and explain the form, growth, and development of actors in the industry, as well as the creation of clusters. ${ }^{13}$ Cultural industries tend to concentrate in a certain place, i.e., to form clusters. As early as 1919, Alfred Marshall researched industrial districts in England, but the basic definition of clusters was given by Porter, ${ }^{14}$ who defined them as "geographical concentrations of interconnected firms and institutions in a particular field".

In the literature, we generally encounter two main approaches to the geographical concentration of the cultural or creative industries; both are based on the factor of concentration. The first approach is based on the locality. Locality is the basic starting point of the theory of concentration.

${ }^{6}$ GAŽOVÁ, Viera. Kulturológia v službách kreovania nových konceptov. Od kulturologickej estetiky ku kultúrnej výchove. In: Acta Culturologia. Zbornike zvedeckej konferencie s medzinárodnou účast’ou venovanej kulturologičke Anne Fischerovej. Bratislava: Univerzita Komenského, 2014.

${ }^{7}$ BUČEK, Milan, REHÁK, Štefan, \& HUDEC, Oto. Kreatína ekonomika_národohospodárske a regionálne podmienky a stimuly. Bratislava: Ekonóm, 2014.

${ }^{8}$ Ibid.; SCOTT, Allen. J. On Hollywood: The place, the industry. Princeton: Princeton University Press, 2005.

${ }^{9}$ KLOUDOVÁ, Jitka. Kreativní ekonomika a její měření. In: Ekonomický časopis, 57(3), 2009, pp. $24-262$.

${ }^{10}$ MURGAŠ, Can Easterlin's paradox..., pp. 3-14.

${ }^{11}$ FLEW, Terry. Towards a Cultural Economic Geography of Creative Industries and Urban Development: Introduction to the Special Issue on Creative Industries and Urban Development. In: The Information Society, 26, 2010, pp. 85-91.

12 ŽIGRAI, František. Prínos kultúrnej geografie pri štúdiu vzt’ahu medzi krajinou, človekom a kultúrou. In: Krajina-človek-kultúra. Banská Bystrica, 1999, pp. 11-115.

${ }^{13}$ GONG, Huiwen \& HASSINK, Robert. What drives the geographies of creative industries? From literature review to research agenda. In: Papers in Innovation Studies 2016/9. Lund University: CIRCLE_Centre for Innovation Research, 2016.

${ }^{14}$ PORTER, Michael. The Competitive Advantage of Nations. New York: The Free Press, 1990, p. 857 
K. Baculáková - M. Grešš: Spatial Distribution Model for Targeting the Support...

According to this approach, cultural industries are concentrated in a certain location and thus enjoy some advantages such as access to customers or specialised service providers. ${ }^{15}$ The second approach focuses on urban areas. According to this approach, cultural industries are more concentrated in cities. ${ }^{16}$ In this approach, the quality of place exceeds the availability of place.

While in other industries, factors directly affecting production and distribution themselves play a role in concentration, in cultural industries, factors influencing actors, especially people working in cultural industries, carry more weight. ${ }^{17}$ This creates new approaches that take into account various factors affecting the comfort and specificity of the place. These include, for example, cultural infrastructure, the quality of public services, the availability of university education, opportunities for cultural, sporting, and leisure activities, diversity, tolerance of diversity, openness, social cohesion, natural and cultural heritage, or local governments. ${ }^{18}$ Several authors emphasise the image of the place, its style, branding, openness, diversity, and tolerance. ${ }^{19}$ The basis of cultural infrastructure is the so-called cultural environment-its existence, as well as the participation of the population in cultural life. ${ }^{20}$

The concentration of cultural industries is not only the result of natural development, but also of targeted policy. In the Visegrad region, the policy to support the development of clusters began to be implemented only in 2005. ${ }^{21}$ This region, and thus also Slovakia, was gradually undergoing a change from a centrally planned economy, where no economic benefit was attributed to culture. Today, cultural clusters make up about $20 \%$ of all creative clusters (as their core) in the V4 region. ${ }^{22}$ Interestingly, however, in Poland and Hungary, cultural clusters are not concentrated in metropolises, as is the case in Slovakia and the Czech Republic. The study by Bialic-Davendra et al. also found that these clusters are strongly supported by public institutions and the non-profit sector. Thus, it can be stated that cultural clusters are still primarily non-commercial in nature. This is in contrast to the work of creative clusters and centres, whose role is, among other things, to ensure their viability and cover operating costs (which was, for example, one of the conditions in the grant call for building creative centres in Slovakia in 2019). However, cultural clusters also show a very low level of activity compared to creative clusters.

Clusters are one of the tools of regional development. At the same time, vital cultural infrastructure is a necessary precondition for creating an environment that will be attractive to

\footnotetext{
${ }^{15}$ BRANZANTI, Caterina. Creative clusters and district economies: Towards a taxonomy to interpret the phenomenon. In: European Planning Studies, 23(7), 2015, pp. 1401-1418.

${ }^{16}$ FLORIDA, Richard. The Rise of the Creative Class: And How It's Transforming Work, Leisure, Community and Everyday Life. New York: Basic Books, 2002; FLORIDA, Richard. Cities and the Creative Class. New York: Routledge, 2005; LAZZERETTI, Luciana, DOMENECH, Rafael Boix, \& CAPONE, Francesco. Do creative industries cluster? Mapping creative local production systems in Italy and Spain. In: Industry and Innovation, 15(5), 2008, pp. 549-567.

${ }^{17}$ FLORIDA, The Rise of...

${ }^{18}$ SELADA, Catarina. Creative Clusters in Low Density Urban Areas: A Case Study Approach, SA Conference Papers ERSA 2010, European Regional Science Association, 2011, accessed October 24th, 2020, http://urbact.eu/ sites/default/files/import/Projects/Creative_Clusters/documents_media/Paper_ERSA_VF_01.pdf

${ }^{19}$ PAREJA-EASTAWAY, Montserrat. The Barcelona Metropolitan Region: From Non-Existence to Fame. In: Built Environment, 35, 2009, pp. 212-219. DOI: 10.2148/benv.35.2.212; CUADRADO-ROWA, Juan. The location of service industries. Service industries and regions. Berlin: Springer, 2013.

${ }^{20}$ CURRID, Elizabeth \& WILLIAMS, Sarah. The Geography of Buzz: Art, Culture and the Social Milieu in Los Angeles and New York. In: Journal of Economic Geography, 10(3), 2010, pp. 1-29. DOI: 1093/jeg/lbp032

${ }^{21}$ BIALIC-DAVENDRA, Magdalena, et al. Creative Clusters in Visegrad Countries: Factors Conditioning Cluster Establishment and Development. In: Bulletin of Geography, Socio-economic Series 32, 2016, pp. 33-47. 10.1515/ bog-2016-0013.

22 Ibid.
} 
the creative class, while its operation in a place or region again contributes to its revitalisation and growth. The individual components-culture, cultural industries, and finally the creative industries - thus interact with each other and multiply the development potential of the place or region. Local authorities and public institutions have an irreplaceable role to play in supporting the development of cultural industries. While Drda-Kühn and Wiegard, ${ }^{23}$ in their research on the relationship between culture, cultural tourism, and regional development, confirmed the importance of public institutions in ensuring cooperation between the various actors, Granger ${ }^{24}$ points out the exact opposite in his study. In Leicester, the United Kingdom, local authorities have failed.

\section{Methods}

Although in most analyses the sectoral approach and orientation to measure the spatial concentration of creativity prevails, rather than measuring culture, for example in the form of the Creativity Index, ${ }^{25}$ today the theory of creative places is highly questioned. ${ }^{26}$ In our analysis, therefore, we draw attention to cultural institutions such as the so-called cultural actors. Cultural institutions participate in the development of cultural life at the regional and local level and thus also contribute to the development of the region. The aim of the presented paper is to determine the spatial concentration of cultural institutions in Slovakia through available statistical data. The intention is to create an overview in which regions and districts' cultural institutions are more represented, and where the allocation of (additional) funds can be considered. The intention was to create a model of spatial concentration, on the basis of which we can support the economic potential of culture, namely specific cultural institutions in a given region or district. The initial assumption of our analysis is that the concentration of cultural institutions will occur in urban areas, especially in larger cities, because they always have a better cultural infrastructure. ${ }^{27}$ In our analysis, we also assume the connection between culture and the creative industry, especially the concentration of creative capital. We assume that the distribution of cultural institutions has an impact on the concentration of the creative class, which, together with culture itself, is also a factor in regional and local development. ${ }^{28}$ The result of the analysis is the identification of regions and districts with the potential for better allocation of funds as well as the setting of cultural policy. In the analysis of the spatial distribution of cultural facilities in regions and districts, we will assume that where the creative class is concentrated, the creative industry will be concentrated, and thus there will be more cultural facilities. ${ }^{29}$

\footnotetext{
${ }^{23}$ DRDA-KUHN, Karin \& WIEGARD, Dietmar. From culture to cultural economic power: Rural regional development in small German communities. In: Creative Industries Journal, 3(1), 2010, pp. 89-96.

${ }^{24}$ GRANGER, Rachel. Creative Splintering and the Rise of Municipal Creative Economies. Leicester: Leicester Castle Business School, 2019.

${ }^{25}$ KLOUDOVÁ, Kreativní ekonomika...

${ }^{26}$ MOULAERT, Frank, DEMUYNCH, Hilde, \& NUSSBAUMER, Jacques. Urban renaissance: From physical beautification to social empowerment. In: City, 8(2), 2004, pp. 229-235; KRATKE, Stefan. Creative Cities and the Rise of the Dealer Class: A Critique of Richard Florida's Approach to Urban Theory. In: International Journal of Urban and Regional Research, 34(4), 2010, pp. 835-853.

${ }^{27}$ FLORIDA, The Rise of...; BIALIC-DAVENDRA et al., Creative Clusters...

${ }^{28}$ FLORIDA, The Rise of...

${ }^{29}$ Ibid; MURGAŠ, František \& ŠEVČĆKOVÁ, Marta. Geografický prístup k meraniu kreatívneho kapitálu Prípadová štúdia: Index kreatívneho kapitálu Slovenska. Creative and Knowledge Society, 1, 2011, pp. 37-56.
} 
To examine the distribution of cultural institutions, we used cluster analysis to decompose a set of objects into several relatively homogeneous subsets (clusters) so that objects belonging to the same cluster are as similar as possible, while objects from different clusters should be as different as possible. In our case, we divided the districts and regions of Slovakia into clusters according to selected available macroeconomic indicators. According to the methodology of cultural potential, we divided cultural institutions into several groups (Tab.1):

Tab. 1. Cultural Institutions

\begin{tabular}{|l|}
\hline $\begin{array}{l}\text { - Museal institution (museum, nature museum, memorial room } \\
\text { etc.) }\end{array}$ \\
\hline - Gallery institution \\
\hline - Library, institution of Literal Culture \\
\hline - Theatre \\
\hline - Cultural and educational centre \\
\hline - Cinema \\
\hline
\end{tabular}

Data from the Data Cube system ${ }^{30}$ of the Statistical Office of the Slovak Republic were used in the analysis. We chose hierarchical cluster analysis, specifically hierarchical agglomeration clustering. The hierarchical system of clusters is characterised by the fact that it creates such a decomposition of the original set of objects, in which each of the partial decompositions is a refinement of the next (so-called agglomerative clustering) or the previous (so-called divisional clustering) decomposition. In addition, agglomerative clustering is a bottom-up approach. Thus, in this approach, the individual clusters are iteratively joined into larger units. The "k-means" method was also tested, which requires the determination of the number of clusters. However, this method only confirmed the optimal results of hierarchical clustering. The set of input data consisted of six monitored variables in eight regions of the Slovak Republic and 79 districts in

$$
\sqrt{\sum_{i=1}^{n}(x i-y i)^{2}}
$$

2018. For the cluster analysis, we chose the Euclidean distance, which is given as:

Ward's minimal variance method was used. In this method, the similarity of objects or clusters is measured as the sum of squares between objects from two clusters, summed over all attributes of the given objects. The uniqueness of this method lies in minimising the amount of variance across all newly formed clusters. This minimises the increase in the amount of square deviation of objects from their centroids. The amount of the square deviation can then be written as:

$$
E=\sum_{K}^{t=1} \sum_{x=C 1}\left\|x_{i}-m_{i}\right\|^{2}
$$

\footnotetext{
${ }^{30}$ DataCube. Kultuira, 2020, accessed November 13th, 2020, http://datacube.statistics.sk/;\#!/folder/sk/1000467
} 


\section{Results}

The result of the first cluster analysis, where we examined 8 regions, is the creation of four clusters:

- Cluster 1: Bratislava Region (BA);

- Cluster 2: Banská Bystrica Region (BB); Prešov Region (PO); Žilina Region (ZA);

- Cluster 3: Košice Region (KE);

- Cluster 4: Trnava Region (TT), Trenčín Region (TN), Nitra Region (NR).

These clusters do not represent the order of regions; the grouping only corresponds to the regions that are most similar in all indicators. We consider a higher number of cultural institutions of individual categories from Table 1 to be a more favorable result. The most favourable result was achieved by Clusters 4 (Nitra Region, Trenčín Region, Trnava Region) and 3 (Košice Region). The second most favourable result was achieved by Cluster 2, i.e., the Banská Bystrica Region, the Prešov Region and the Žilina Region. We also found inconsistent results in individual groups-especially in the area of the number of theatres and cinemas. The Bratislava region absolutely dominates in the number of libraries, which is undoubtedly influenced by the number of educational institutions in this region. The Nitra region dominates in the number of museums and galleries. It is also strongly represented in the location of cultural and educational centres. A dendrogram (Fig. 2) shows the formation of clusters from top to bottom, i.e., from the level when the objects in the cluster are most similar. The graphical distribution of clusters is shown on the map in Figure 3:

Fig. 2. Dendrogram of clusters of regions

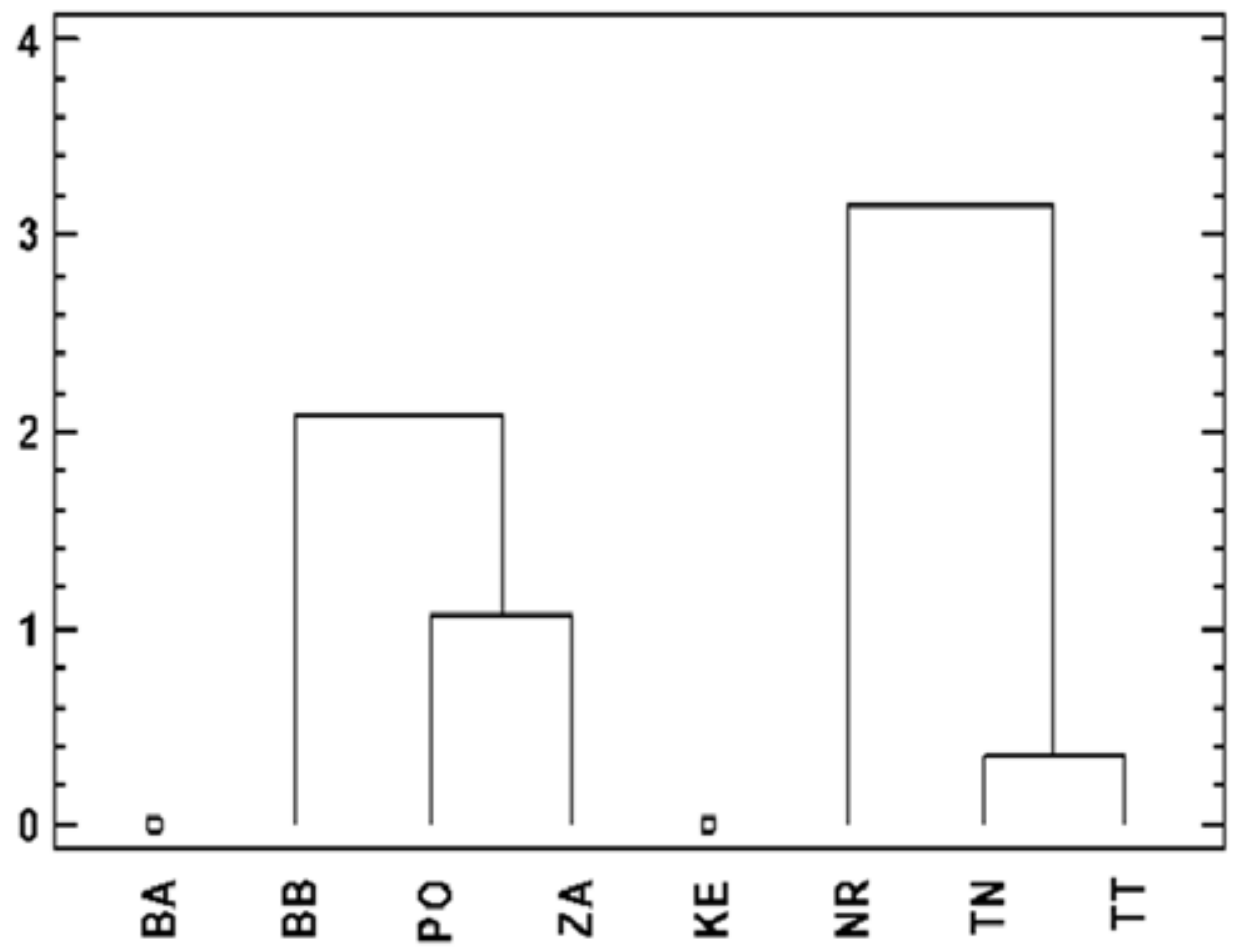


Fig. 3. Map of clusters of regions

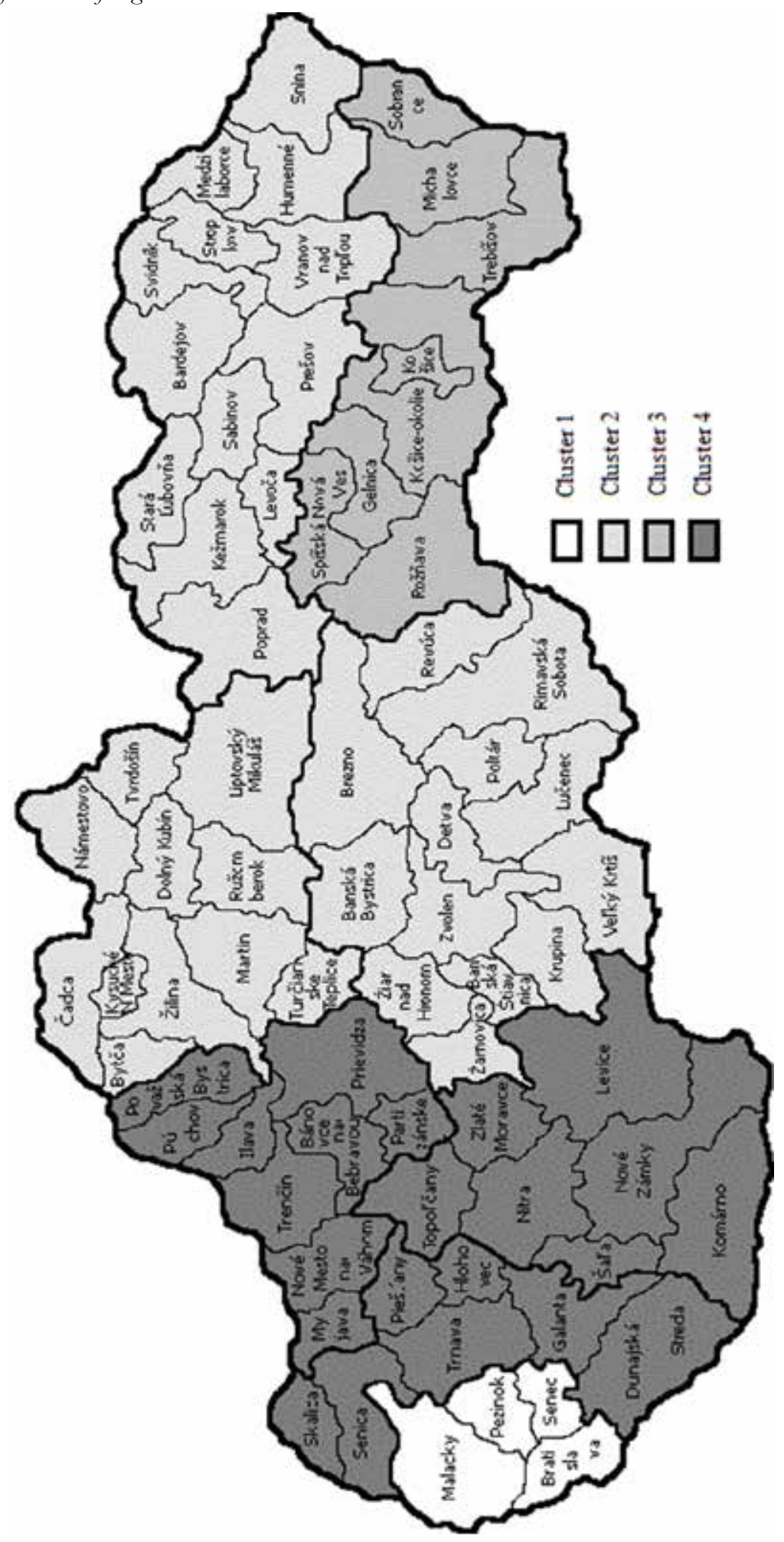


The second cluster analysis determined the division of districts into clusters according to selected indicators. The result of the analysis is the creation of 4 clusters (dendrogram in Figure 4 and graphical layout of map clusters in Figure 5).

- Cluster 1: Bratislava I;

- Cluster 2: Bratislava II, Bratislava III, Bratislava IV, Bratislava V, Pezinok, Skalica, Ružomberok, Banská Bystrica, Banská Štiavnica, Svidník, Košice I;

- Cluster 3: Malacky, Dunajská Streda, Galanta, Piešt’any, Trnava, Nové Mesto nad Váhom, Prievidza, Trenčín, Komárno, Levice, Nitra, Nové Zámky, Topol’čany, Čadca, Dolný Kubín, Liptovský Mikuláš, Martin, Žilina, Brezno, Lučenec, Vel'ký Krtîš, Zvolen, Bardejov, Kežmarok, Poprad, Prešov, Sabinov, Stará Lubovňa, Košice - surroundings, Rožňava, Spišská Nová Ves;

- Cluster 4: Senec, Hlohovec, Senica, Bánovce nad Bebravou, Ilava, Myjava, Partizánske, Považská Bystrica, Púchov, Šala, Zlaté Moravce, Bytča, Kysucké Nové Mesto, Námestovo, Turčianske Teplice, Tvrdošín, Detva, Krupina, Poltár, Revúca, Rimavská Sobota, Žarnovica, Žiar nad Hronom, Humenné, Levoča, Medzilaborce, Snina

Stropkov, Vranov nad Toplou, Gelnica, Košice II, Košice III, Košice IV, Michalovce, Sobrance.

Fig. 4. Dendrogram of clusters of districts

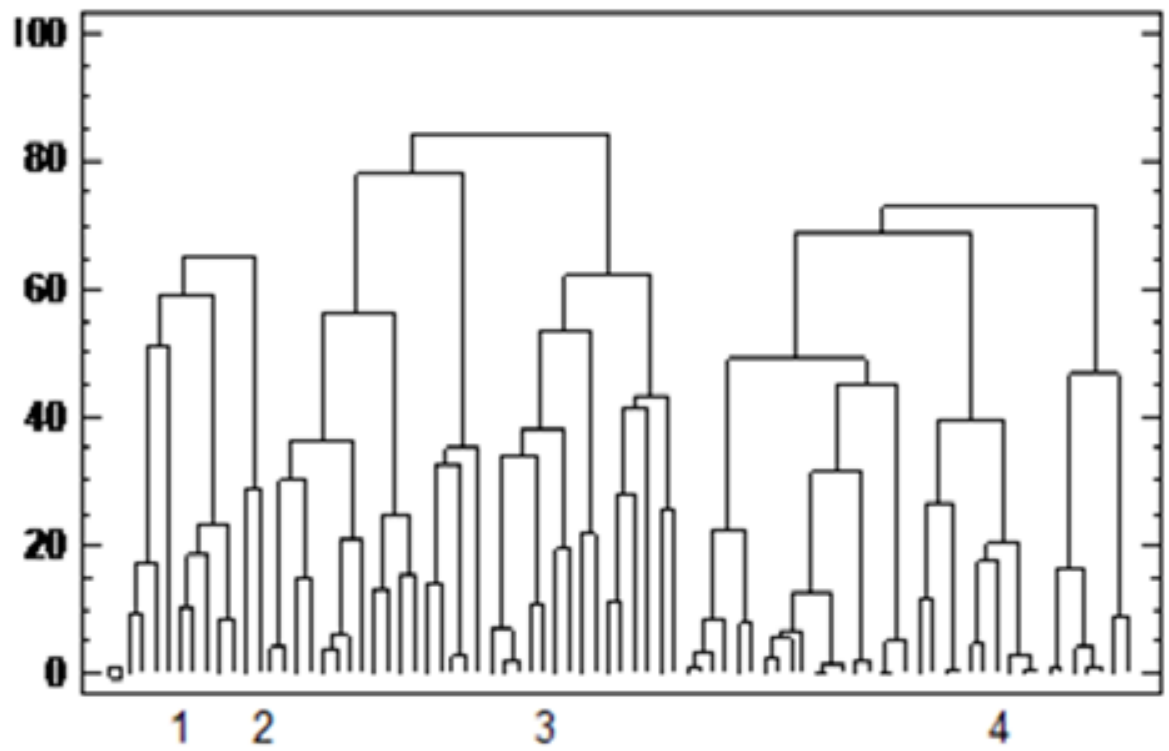


Fig. 5. Map of clusters of districts

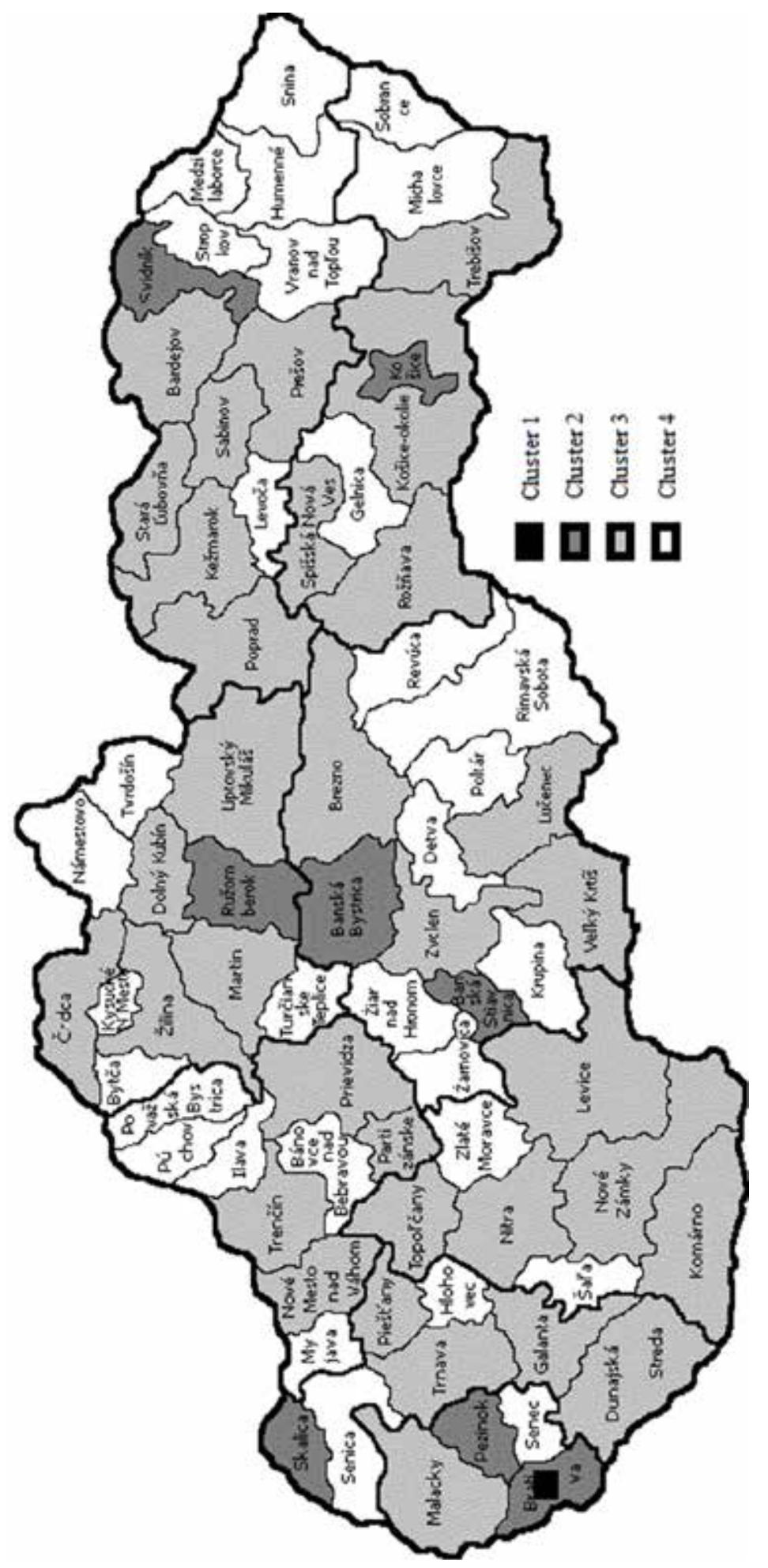


The most favourable results in the selected indicators are achieved by Cluster 3 followed by Cluster 4. It is interesting that within Bratislava as one city, there are big differences in individual city districts. In fact, only Bratislava I, which represents the Old Town, reaches a more significant position. It is (already from a historical point of view) the cultural centre of the whole capital. Representation of cultural institutions in other parts of the city is very weak even within the least favourable Cluster 2.

Tab. 2. Cultural institutions in the districts of Bratislava I-V

\begin{tabular}{|l|l|l|l|l|l|}
\hline District & Theatres & Libraries & $\begin{array}{l}\text { Cultural- } \\
\text { educational } \\
\text { centres }\end{array}$ & Cinemas & $\begin{array}{l}\text { Museums and } \\
\text { galleries }\end{array}$ \\
\hline Bratislava I & 2 & 21 & 2 & 6 & 1 \\
\hline Bratislava II & 5 & 4 & 3 & 2 & 7 \\
\hline Bratislava III & 2 & 2 & 3 & 1 & 3 \\
\hline Bratislava IV & 1 & 5 & 6 & 5 & 6 \\
\hline Bratislava V & 4 & 6 & 2 & 5 \\
\hline
\end{tabular}

The results of the cluster analysis in the regions of Slovakia do not completely correspond to the results of the analysis in the districts of Slovakia. An example is that within the most successful Cluster 3 in the analysis of regions we see significant differences between individual districts, some of which already belong to another, less favourable Cluster 4.

The clusters with the most favourable indicators are characterised by:

- concentration of cultural industries (Bratislava, Trnava, Nitra, Košice);

- representation of educational institutions (universities);

- good transport accessibility;

- economic strength (these are always economically stronger districts);

- in the case of Bratislava, specific factors can also be considered, such as cosmopolitanism and the European character of the city, which predestines it to the position of the cultural centre of Slovakia.

\section{Discussion and Conclusion}

The cluster analysis pointed out significant differences in the representation of cultural institutions in individual regions and districts of Slovakia. The regions with the best results (especially Bratislava, Trnava, or Nitra) have some common characteristics. One of the common denominators of the better results of these regions is the historical development and their current position in the territorial division of Slovakia. Bratislava as the capital is a traditional centre of culture throughout the country. These results are also in line with the research of Murgaš, ${ }^{31}$ who measured creativity in individual regions of Slovakia. He even described Bratislava as "the pole of creativity", 32 so we can also call it a pole of culture in Slovakia. This confirms the fact that the availability of quality cultural infrastructure can attract the creative class and vice versa - the presence of the creative class in the region stimulates the

${ }^{31}$ MURGAŠ \& ŠEVČĆKOVÁ, Geografický prístup..., pp. 37-56.

${ }^{32}$ Ibid. 
K. Baculáková - M. Grešš: Spatial Distribution Model for Targeting the Support...

further development of cultural institutions. ${ }^{33}$

The districts of Prešov, Košice, and Banská Bystrica have a traditionally strong theatrical representation, Nitra dominates in the number of museums and galleries, and finally Košice as the metropolis of eastern Slovakia is not only a natural socio-economic centre of eastern Slovakia but also a centre of culture. The regions of western Slovakia have a high quality transport infrastructure with good accessibility. They are the centres of educational institutions, and education increases interest and demand for culture. Unsatisfactory cooperation of educational institutions with actors in cultural industries does not lead to the growth of the region, but, on the contrary, hampers development. ${ }^{34}$

The results also confirmed the assumption that within the regions, cultural institutions will be concentrated in larger district cities. ${ }^{35}$ Specifically, in the case of Bratislava, the statement that they are concentrated within the city also applies, similarly to the analysis of Gregory and Rogerson. ${ }^{36}$ It is interesting to compare the results of the analysis of the spatial concentration of cultural institutions and the spatial differentiation of quality of life in Slovakia. According to Murgaš ${ }^{37}$ the regional division of Slovakia speaks of the prosperous northwest of the country and the undeveloped southeast of the country. In part, this statement can be identified with our results-from the cluster analysis we can observe a belt of districts of southern, central, and eastern Slovakia, which do not have sufficient cultural infrastructure. These results are in line with the results of the analysis of the spatial differentiation of cultural capital as part of human capital. Also, in our results, the differentiating element is the position of some districts of the Prešov or Košice region. On the other hand, rather than southern Slovakia, the districts of central Slovakia ranked worse in the analysis of districts.

A higher concentration of cultural institutions is naturally created even in places with a concentration of the creative class. In this process, it not only acts as a creator of culture and a bearer of creativity, but above all it creates a demand for cultural institutions. At present, this demand is transformed and there is an increasing interest in new forms of cultural institutions and facilities (community centres and co-workshops, which serve not only as workspaces but also provide spaces where cultural events or interactive creative workshops take place on a regular basis).

An indispensable factor, which is strongly present in the analysis, is the economic maturity of regions (more specifically districts). The hierarchy of human needs is already clear from Maslow's pyramid. Only when one is able to satisfy one's primary physical needs does the need for self-realisation arise, with the need for aesthetics and culture at the very top of the pyramid. Unfortunately, in the economically weakest regions in the south of central Slovakia, or in the former mining areas, this situation is alarming. Lack of jobs and high unemployment do not encourage citizen participation in culture or encourage creativity. Cultural and social disparities between the inhabitants of economically prosperous areas and lagging areas are growing. ${ }^{38}$ Slušná, on the other hand, also draws attention to the so-called stigmatisation of the population from the relevant economically weaker regions, while such stigmatisation (especially the medial

\footnotetext{
${ }^{33}$ FLORIDA, The Rise of...

${ }^{34}$ GRANGER, Creative Splintering...

${ }^{35}$ FLORIDA, The Rise of...; BIALIC-DAVENDRA et al., Creative Clusters...

${ }^{36}$ GREGORY, James \& ROGERSON, Christina M. Suburban creativity: The geography of creative industries in Johannesburg. In: Bulletin of Geography Socio-economic Series 39, 2018, pp. 31-52.

${ }^{37}$ MURGAŠ, Kvalita života...

${ }^{38}$ SLUŠNÁ, Súčasná kultúrna...
} 
one) causes apathy in the population and the inability to identify the cultural potential of their region and turn it into its cultural asset.

Culture is one of the pillars of an educational society. It not only creates aesthetic and ethical values, but is also a sector with promising economic potential. It follows that cultural industries are one of the few in which there is a natural interconnection of intangible and economic values. Agenda 21 for Culture presents culture as the fourth pillar of regional development. Slovakia is not an urban country - it is one of the OECD countries with a higher share of rural population, so there is no so-called metropolitan culture and it is more strongly dominated by local culture or cultural heritage. It is similar to Poland and Hungary. ${ }^{39}$

Knowledge of the spatial concentration of cultural potential and cultural industries, as well as cultural institutions, is essential in shaping cultural policy and developing the cultural potential of the country. Cultural policy is an inseparable tool for the management of culture and cultural and creative industries today. It also addresses the management and functioning of culture. The scope of cultural policy today is very wide. It ensures adequate protection of cultural heritage, ${ }^{40}$ and sets the allocation of financial resources, which has a direct impact on the development of regions, the creation of employment in culture, and the mobilisation of cultural potential. It regulates the management and administration of cultural facilities and institutions, and sets up education in the field of culture. Given that cultural policy de facto creates the conditions for the functioning of culture in the country, it is desirable that it will be based on the current needs of individual regions. It is therefore not possible to create an effective and functioning cultural policy without first mapping the state of culture in regions and districts, and without knowing their cultural potential and the spatial concentration of cultural industries, whose support has now become an integral part of the EU cultural policies. Such mapping and deeper-especially continuous - research in the subject matter with the involvement of all relevant actors has not yet taken place in Slovakia.

In our analysis, the statistical model included the territorial division of the country into regions and districts. This was introduced in 1996 and does not fully reflect the historical regions to which the common cultural tradition is understandably linked. This can be considered a shortcoming of the model. However, due to the allocation of funds from the Regional Operational Program, the model offered a view of the districts that could become potential beneficiaries of support. Spatial analysis therefore enables the creation of a picture of the current state of cultural institutions and the demand for culture and is a tool for identifying the strengths and weaknesses, needs and opportunities of regions and districts, as well as targeted resource allocation. It is therefore a basic precondition for creating and shaping a functioning cultural policy. In the future, it will be necessary not only to apply established models of cultural development, but also to respond flexibly to changing trends in the operation of cultural industries. It can be unequivocally argued that traditional cultural industries are beginning to be pushed aside. ${ }^{41}$ It is therefore necessary to constantly remember the differences between culture and the creative industry, because the primary meaning of culture is not its economisation. Another trend is the transfer of culture and cultural activities out of the city, i.e., into the suburbs. This trend is not so visible in Slovakia yet, but in the future, it will be necessary to take it into account. It can be seen as positive, as the concentration of culture in suburbs and former

\footnotetext{
${ }^{39}$ BIALIC-DAVENDRA et al., Creative Clusters...

${ }^{40}$ SLUŠNÁ, Súčasná kultúrna...

${ }^{41}$ BEDNÁŘ, Pavel \& GŘEBENÍČEK, Pavel. Mapping Creative Industries in the Zlin Region. In: Journal of Competitiveness, 1, 2012, pp. 20-35.
} 
K. Baculáková - M. Grešš: Spatial Distribution Model for Targeting the Support...

industrial areas contributes to their revitalisation. ${ }^{42}$

As stated in the Strategy for the Development of Culture of the Slovak Republic for the years 2014-2020, there is a discrepancy between the attitude of society towards culture at the declarative level and the actual position of culture which is acknowledged by the society. ${ }^{43}$ The financing of culture in Slovakia has long been underestimated (especially in comparison with other EU countries), while the data distorted the funds that flowed from the Ministry of Culture to support churches. One of the possibilities today seems to be the use of structural funds, but experience shows that Slovakia is not able to use the structural funds effectively. Moreover, from a political point of view, there is a certain discontinuity in the field of cultural policy-making. This formation was largely subject to changes in the political set. The strategy further states that one of the biggest obstacles to the development of culture is the low demand for it, while expenditures on culture represent only about $1 \%$ of the total monthly expenditures of an individual household.

On the positive side, cultural institutions (as cultural actors) are one of the strengths of culture in Slovakia. Their network and representation in individual regions and districts is relatively wide, even in less developed districts. This creates good preconditions for increasing the cultural offer. However, the inadequate technical conditions and material and technical equipment of some of them act as an impedance on the development of culture and the transformation of cultural potential into cultural capital in a given region. As a result of this unsatisfactory status, as well as the non-professional management system of cultural institutions, their inefficient functioning occurs very often. We therefore identify two key (though not the only) problems of cultural development in Slovakia-insufficient funding (both public and private, Table 3) and low demand for culture (which is also spatially differentiated). Compared to other V4 countries, the value of public expenditure on culture (per capita) in Slovakia is the lowest. The largest share of cultural expenditure in Slovakia has long been allocated to cultural heritage policy.

Tab. 3. Financing culture and participation in culture in selected countries

Ministry of Culture of the Slovak Republic, Eurostat

\begin{tabular}{|c|c|c|c|c|c|}
\hline & Slovak Republic & EÚ & Czech Republic & Hungary & Poland \\
\hline $\begin{array}{l}\text { Citizen participation in culture } \\
\%\end{array}$ & $59,40 \%$ & $63,70 \%$ & $70,20 \%$ & $49,20 \%$ & $56 \%$ \\
\hline $\begin{array}{l}\text { Financing } \\
\% \text { GDP }\end{array}$ & $0,76 \%$ & $0,73 \%$ & $0,96 \%$ & $1,72 \%$ & $0,75 \%$ \\
\hline Resources & $\begin{array}{l}60 \% \text { public expenditures } \\
40 \% \text { municipalities }\end{array}$ & \multirow{4}{*}{\multicolumn{4}{|c|}{$\mathrm{N} / \mathrm{A}$}} \\
\hline Theatres & 38 mil. EUR & & & & \\
\hline Museums and galleries & 34 mil. EUR & & & & \\
\hline Libraries & 30 mil. EUR & & & & \\
\hline
\end{tabular}

${ }^{42}$ GREGORY \& ROGERSON, Suburban creativity...

${ }^{43}$ MINISTERSTVO KULTÚRY SR. Stratégia rozvoja kultúry Slovenskej republiky na roky 2014-2020, 2014, accessed November 2nd, 2020, http://www.strategiakultury.sk/sites/default/files/STRATEGIAROZVOJA_KULTURY_SR_NA_ROKY_2014-2020.pdf 
Dignified administration and decent reconstruction of cultural heritage is undoubtedly one of the key areas of cultural care. However, when we talk about boosting the economic potential of culture with emphasis on the development of regions, it is necessary to respond flexibly to new trends and stimulate young generations to live within culture. It will therefore be necessary to focus on new forms of cultural institutions that come to the fore and are especially popular with the younger generation-such as community and co-working centres, creative labs, and multifunctional cultural spaces. Examples of the use of the Structural Funds could be successful European projects in the field of cultural infrastructure, cultural activities, and cultural production or the revitalisation of urban areas and their transformation into cultural centres, namely the reconstruction of the Zollverein industrial complex in the Ruhr area, cultural tourism in Greece and Portugal, and Musikpark Mannheim as a combination of cultural and commercial facilities etc. Successful programmes are also being launched in Slovakia, for example the planned creative centre in Trnava, which will be located in the revitalised historic building in the city centre and will provide studios, professional graphic studios, and workshops for working with wood and metal, as well as music rehearsal rooms, concert venues, and a lecture hall. It will also create adequate conditions for the development of business skills. Out of the total project budget, 7.7 million EUR will be obtained from the European funds. ${ }^{44}$

In conclusion, to eliminate the shortcomings in the support and development of cultural institutions, it will be necessary to set up a functioning system for financing culture in the next financing period of 2020-2027, especially with regard to the spatial concentration of culture. The planned creation of creative centres in the regions of Slovakia from the Integrated Regional Operational Programme-Priority Axis 3, which are not primarily cultural institutions in the true sense of the word, can create a synergistic effect and help concentrate the creative class in the region, and thus increase the demand for culture, cultural services and goods. At the same time, it will be necessary to strengthen the absorption of structural funds in the field of culture, which Slovakia has so far failed to use effectively. The second important area is the educational process and cultural literacy, where educational institutions play an important role at every level of education.

\section{References}

BEDNÁř, Pavel \& GŘEBENÍČEK, Pavel (2012). Mapping Creative Industries in the Zlin Region. Journal of Competitiveness, 1, pp. 20-35.

BIALIC-DAVENDRA, Magdalena, BEDNÁŘ, Pavel, DANKO, Lukáš, \& MATOŠKOVÁ, Jana (2016). Creative Clusters in Visegrad Countries: Factors Conditioning Cluster Establishment and Development. Bulletin of Geography, Socio-economic Series 32, pp. 33-47. 10.1515/bog-2016-0013.

BOIX, Rafael et al. Micro-geographies of creative industries clusters in Europe: From hot spots to assemblages. In Papers in Regional Science. 2013. 94/4. pp.753-772.

BORDIEU, Pierre (1986). The forms of capital. In: J. Richardson (ed.), Handbook of Theory and Research for the Sociology of Education. Westport, CT: Greenwood, pp. 241-58.

\footnotetext{
${ }^{44}$ TRNAVSKÝ SAMOSPRÁVNY KRAJ. Župa začne stavat' Kreativne centrum Trnava, o projekt sa zaujimala aj ministerka kultury, 2021, accessed on 11th August, 2021, https://www.trnava-vuc.sk/aktuality/zupa-zacne-stavat-kreativne-centrum-trnava-o-projekt-sa-zaujimala-aj-ministerka-kultury/
} 
K. Baculáková - M. Grešš: Spatial Distribution Model for Targeting the Support...

BRANZANTI, Caterina (2015). Creative clusters and district economies: Towards a taxonomy to interpret the phenomenon. In: European Planning Studies, 23(7), pp. 1401-1418.

BUČEK, Milan, REHÁK, Štefan, \& HUDEC, Oto (2014). Kreatívna ekonomika — národohospodárske a regionálne podmienky a stimuly. Bratislava: Ekonóm.

CUADRADO-ROWA, Juan (2013). The location of service industries. Service industries and regions. Berlin: Springer.

CURRID, Elizabeth \& WILLIAMS, Sarah (2010). The Geography of Buzz: Art, Culture and the Social Milieu in Los Angeles and New York. In: Journal of Economic Geography, 10(3), pp. 1-29. doi.1093/jeg/lbp032

DataCube (2020). Kultúra. Available at: http://datacube.statistics.sk/;\#!/folder/sk/1000467

DRDA-KUHN, Karin \& WIEGARD, Dietmar (2010). From culture to cultural economic power: Rural regional development in small German communities. In: Creative Industries Journal, 3(1), pp. 89-96.

EY (2014). Creating Growth: Measuring cultural and creative markets in the EU. Accessed October 15th, 2020, http://www.creatingeurope.eu/en/wp-content/uploads/2014/11/study-fullen.pdf

FLEW, Terry (2010). Towards a Cultural Economic Geography of Creative Industries and Urban Development: Introduction to the Special Issue on Creative Industries and Urban Development. The Information Society, 26, pp. 85-91.

FLORIDA, Richard (2002). The Rise of the Creative Class: And How It's Transforming Work, Leisure, Community and Everyday Life. New York: Basic Books.

FLORIDA, Richard (2005). Cities and the Creative Class. New York: Routledge.

GAŽOVÁ, Viera (2014). Kulturológia v službách kreovania nových konceptov. Od kulturologickej estetiky ku kultúrnej výchove. In: Acta Culturologia. Zbornik z vedeckej konferencie s medżinárodnou účast’ou venovanej kulturologičke Anne Fischerovej. Bratislava: Univerzita Komenského.

GONG, Huiwen \& HASSINK, Robert (2016). What drives the geographies of creative industries? From literature review to research agenda. In: Papers in Innovation Studies 2016/9. Lund University: CIRCLE_Centre for Innovation Research.

GRANGER, Rachel (2019). Creative Splintering and the Rise of Municipal Creative Economies. Leicester: Leicester Castle Business School.

GREGORY, James \& ROGERSON, Christina M. (2018). Suburban creativity: The geography of creative industries in Johannesburg. Bulletin of Geography, Socio-economic Series 39, pp. $31-52$.

ILMONEN, Kari (2015). The Role of Culture in Regional Development Work-Changes and Tensions. In: F. M. Go, A. Lemmetyinen, \& U. Hakala (eds.), Harnessing Place Branding through Cultural Entrepreneurship. London: Palgrave Macmillan, pp. 79-95.

JACKSON, Maria, KABWASA-GREEN, F., \& HERRANZ, J. R. (2006). Cultural Vitality in Communities: Interpretation and Indicators. Washington DC: The Urban Institute.

JANTO, Juraj (2013). Kultúrny a sociálny kapitál lokality ako prostriedok miestneho rozvoja. In: Muzeológia a kulturne dedićstvo, 1(1), pp. 83-99.

KLOUDOVÁ, Jitka (2009). Kreativní ekonomika a její měření. Ekonomický časopis, 57(3), pp. $247-262$. 
KLEIN, Juan Luis, TREMBLAY, D.G., SAUVAGE, Laurent, GHAFFARI, Leila, \& ANGULO, Wilfredo (2019). Cultural Initiatives and Local Development: A Basis for Inclusive Neighborhood Revitalization. Urban Planning, 4(1), pp. 78-90. 10.17645/up.v4i1.1658.2012.

KRATKE, Stefan (2010). Creative Cities and the Rise of the Dealer Class: A Critique of Richard Florida's Approach to Urban Theory. International Journal of Urban and Regional Research, 34(4), pp. 835-853.

LAZZERETTI, Luciana, DOMENECH, Rafael Boix, \& CAPONE, Francesco (2008). Do creative industries cluster? Mapping creative local production systems in Italy and Spain. Industry and Innovation, 15, pp. 549-567.

LENOVSKÝ, Ladislav, ČUKAN, Jaroslav, DUBSKÁ, Michala, \& MICHALÍK, Boris (2014). Hodnotiaci model kultúrneho potenciálu. Nitra: Univerzita Konštantína Filozofa.

MARSHALL, Alfred (1919). Industry and Trade. London: Macmillan.

MINISTERSTVO KULTÚRY SR (2019). Revízia výdavkov na kultúru, accessed November 2nd, 2020, http://www.culture.gov.sk/extdoc/8339/Revizia $\% 20$ vydavkov $\% 20$ na $\% 20$ kulturu\%20priebezna $\% 20$ sprava

MINISTERSTVO KULTÚRY SR (2014). Stratégia rozvoja kultúry Slovenskej republiky na roky 2014-2020, accessed November 2nd, 2020, http://www.strategiakultury.sk/sites/default/ files/STRATEGIAROZVOJA_KULTURY_SR_NA_

ROKY_2014-2020.pdf

MISTRÍK, Erich, HAAPANEN, Satu, HEIKKINEN, Hannu, JAZUDEK, Roman, ONDRUŠKOVÁ, Nataša, \& RÄSÄNEN, Rauni (1999). Kultúra a multikultúrna výchova. Bratislava: Iris.

MOULAERT, Frank, DEMUYNCH, Hilde, \& NUSSBAUMER, Jacques (2004). Urban renaissance: From physical beautification to social empowerment. In: City, 8(2), pp. 229-235.

MURGAŠ, František (2009). Kvalita života a jej priestorová diferenciácia v okresoch Slovenska. In: Geografický časopis, 61(2), pp. 121-138.

MURGAŠ, František \& ŠEVČÍKOVÁ, Marta (2011). Geografický prístup k meraniu kreatívneho kapitálu Prípadová štúdia: Index kreatívneho kapitálu Slovenska. In: Creative and Knowledge Society, 1, pp. 37-56.

MURGAŠ, František (2019). Can Easterlin's paradox be applied to the development of satisfaction with life or does the explanation lie in cultural geographical characteristics? In: Geografický časopis, 71(1), pp. 3-14.

PAREJA-EASTAWAY, Montserrat (2009). The Barcelona Metropolitan Region: From NonExistence to Fame. Built Environment, 35, pp. 212-219. DOI: 10.2148/benv.35.2.212.

PRAVDOVÁ, Hana (2015). Manažment a marketing v kultúrnych inštitúciách. Bratislava: Univerzita Komenského.

PORTER, Michael (1990). The Competitive Advantage of Nations. New York: The Free Press.

SELADA, Catarina (2011). Creative Clusters in Low Density Urban Areas: A Case Study Approach, SA Conference Papers ERSA 2010, European Regional Science Association, accessed October 24th, 2020, http://urbact.eu/sites/default/files/import/Projects/Creative_Clusters/ documents_media/Paper_ERSA_VF_01.pdf

SCOTT, Allen (2005). On Hollywood: The place, the industry. Princeton: Princeton University Press.

SLUŠNÁ, Zuzana (2015). Súčasná kulturna situácia z.pobl’adu teórie a praxe. Bratislava: Univerzita Komenského.

SOUKUP, Václav (2000). Sociálni a kulturni antropologie. Praha: Slon. 
K. Baculáková - M. Grešš: Spatial Distribution Model for Targeting the Support...

THORSBY, David (2001). Economics and Culture. Cambridge: Cambridge University Press.

TRNAVSKÝ SAMOSPRÁVNY KRAJ (2021). Župa začne stavat' Kreativne centrum Trnava, o projekt sa zaujimala aj ministerka kultury. https://www.trnava-vuc.sk/aktuality/zupa-zacnestavat-kreativne-centrum-trnava-o-projekt-sa-zaujimala-aj-ministerka-kultury/

TYLOR, Edward (1871). Primitive Culture. Cambridge: Cambridge Library Collection.

ŽIGRAI, František (1999). Prínos kultúrnej geografie pri štúdiu vzt'ahu medzi krajinou, človekom a kultúrou. In: Krajina-človek-kultúra. Banská Bystrica, pp. 110-115. 